\title{
Investigation of ultrasound pretreatment time and microwave power level on drying and rehydration kinetics of green olives
}

\author{
Alev Yüksel AYDAR ${ }^{1 *}$
}

\begin{abstract}
In this study, the effect of ultrasound (US) combined microwave (MW) drying of green olive slices was studied. Olive samples were exposed to ultrasound ( 5 and 10 minutes; $32 \mathrm{KHz}$ ) at room temperature before dried at microwave at 3 different power level $(180 \mathrm{~W}, 450 \mathrm{~W}$ and $800 \mathrm{~W})$. The drying and rehydration characteristics and quality parameters of olives were determined by comparing with obtained by non-ultrasound pretreated MW dried samples. Midilli et al.and Diffusion models were the most suitable models for US-MW drying with the highest $\mathrm{R}^{2}$, and lowest RMSE and chi square values. Total phenolic compounds (TPC) of olive slices reduced during drying in all treatments, however TPC of ultrasound pretreated samples were relatively higher those non treated samples dried at same microwave. Increasing of microwave level and ultrasound time decreased the total drying time up to \%42.5. This study showed that US-MW can be a useful combine drying method for olive slices which decreased the drying time and improved the qualitative properties of olives.
\end{abstract}

Keywords: ultrasound; microwave; drying; olive; kinetic model; rehydration.

Practical Application: Ultrasound combined microwave drying of olives can be used as a new drying method in food industry.

\section{Introduction}

Olive (Olea Europea) is one of the most consumed fruits in Mediterranean countries with its superior properties such as high concentration of vitamin $\mathrm{E}$ and phenolic compounds including oleuropein, tyrosol and hydroxytyrosol (Aydar et al., 2017a). It is evaluated and consumed mostly as table olive and olive oil after harvesting. Fresh olives are high in nutrients but can be easily spoiled due to high water activity until processing (Kailis, 2016).

Drying is a widely applied method which aims reducing water activity (aw) of foods to storage for long-term as well as to lower the weight of food and volume to reduce shipping costs (Antal et al., 2017). Hot air drying is one of the commonly used methods for drying of fruits and vegetables, but, it has many disadvantages, such as long drying time, loss in nutritional content, undesirable product deterioration and low energy efficiency (Horuz et al., 2017). Freeze drying obtains high quality products, however it associates with high energy consumption and long drying time. Microwave drying or radio frequency are also used by many researchers to replace conventional drying and shortened the drying time and improved product quality, but they still have drawbacks over conventional hot air drying such as their non-uniform heating characteristics and unstable temperature control (Rodríguez et al., 2007; Tang et al., 2005; Yildiz \& İzli, 2019). Therefore it is necessary to develop new combine drying methods or pretreatments to attain improved drying process and enhanced product quality (Rawson et al., 2011).

Ultrasound is a novel technology has been used in many food processing and applications such as dairy and beverage technology (Ahmad et al., 2019; Guimarães et al., 2018, 2019a, b), oil extraction (Aydar et al., 2017b; Jiménez et al., 2007) and as a pretreatment in drying of foods (Huang et al., 2019). Ultrasound pretreatment accelerates the mass transfer in drying mainly due to breakdown of cells and formation of micro channels (Sun, 2014). In the last decade, ultrasound has been applied as a pretreatment in hot air drying of many fruits and vegetables such as tomato (Horuz et al., 2017), kiwifruit (Wang et al., 2019), okra (Sunil et al., 2017), garlic (Bozkir et al., 2018), apple (Fijalkowska et al., 2016) and mushroom (Zhang et al., 2016). However there is no study investigated the combined effect of ultrasound and microwave drying on quality characteristics and drying parameters of green olive slices. Therefore, in this study different minutes of sonication was applied as a pretreatment to the microwave drying of olive slices to describe the effect of ultrasound process on enhancement of the microwave drying and rehydration process.

\section{Materials and methods}

\subsection{Olive samples}

Fresh olives (Domat variety) were acquired in a local olive company (Aydar Inc, Akhisar, Manisa) and processed at the same day. In order to confirm the sample uniformity, olives which has $20 \mathrm{~mm} \pm 2$ of diameter were chosen for this study and the olives were cut in slices of $5 \mathrm{~mm}$ thickness.

\subsection{Ultrasound treatment}

The green olive slices were put in a $250-\mathrm{mL}$ glass beaker. The distilled water was used as the medium and the ratio of olive slices to water was $1: 5(\mathrm{w} / \mathrm{w})$. The 5 and 10 minutes of ultrasound 
were applied to samples using ultrasonic bath (AlexMachine, PR-6711, Turkey, $150 \mathrm{~kW}$ and ultrasonic frequency $25 \mathrm{KHz}$; Tank volume $4.5 \mathrm{~L}$ ) in this study. An infrared thermometer (Benetech, GM300, China) was used to measure the surface temperature of the olive slices and ultrasonic bath for 1 minute intervals during sonication process. The temperature inside the bath and surface of olive slices did not exceed to $25^{\circ} \mathrm{C}$ during sonication.

\subsection{Microwave drying}

A microwave oven (GE83X, Samsung, Turkey, $2450 \mathrm{MHz}$ and $23 \mathrm{~L}$ capacity) was used for drying of green olive slices. $5 \mathrm{~g}$ of sliced olives were weighed and put on a glass drying tray (10 cm diameter). Then they were left to dry at 180,450 , and $800 \mathrm{~W}$ microwave power levels. The weight of olive slices were recorded in every 1 min during microwave drying until the final moisture content of samples reached approximately $\% 10(\mathrm{w} / \mathrm{w})$. The experiments were performed in triplicate.

\subsection{Mathematical fitting}

Both drying and rehydration kinetics of all samples, with the different treatments, were evaluated using the appropriate mathematical models. In order to determine the best model for describing the drying kinetics behavior, four empirical mathematical models (Table 1) were evaluated. These were selected considering its simplicity and expressive use in the literature (Wang et al., 2019).

The moisture ratio (MR) of green table olive slices was calculated from Equation 1 (Wang et al., 2019)

$\mathrm{MR}=\frac{\mathrm{M}_{\mathrm{t}}-\mathrm{M}_{\mathrm{e}}}{\mathrm{M}_{0}-\mathrm{M}_{\mathrm{e}}}$

Where $M_{t}$ is the moisture at a specific time (w/w), $M_{o}$ is the initial moisture content $(w / w), M_{e}$ is the equilibrium moisture content $(\mathrm{w} / \mathrm{w})$, When moisture at a specific time and initial moisture content are compared with equilibrium moisture content, $M_{e}$ value approaches to a very small number. Therefore, $M R$ is simplified by many researchers and MR of green table olive slices were calculated as this simplified Equation 2 (Midilli et al., 2002):

$\mathrm{MR}=\frac{\mathrm{M}_{\mathrm{t}}}{\mathrm{M}_{0}}$

Drying rates of different drying processes were computed according to Equation 3 (Akpinar et al., 2003):

$\mathrm{DR}=\frac{\mathrm{M}_{\mathrm{t} 1}-\mathrm{M}_{\mathrm{t} 2}}{\mathrm{t}_{2}-\mathrm{t}_{1}}$

Where $t_{1}$ and $t_{2}$ are the different drying times and $M_{t 1}$ and $M_{t 2}$ are the moisture contents of olive slices at time $t_{1}$ and $t_{2}$, respectively.

Henderson and Pabis, Logarithmic, Wang and Sing, and Diffusion models have been applied to describe the changes in moisture content and physicochemical degradation of olive slices during drying are shown Table 2 (Aregbesola et al., 2015; Simal et al., 2005; Wang et al., 2019). A graph of moisture ratio (MR) and drying rates (DR) against time $(\mathrm{t})$ at the different microwave
Table 1. Mathematical models evaluated for the microwave drying of green olive slices with and without ultrasonic pre-treatment.

\begin{tabular}{ccc} 
Model name & Model & References \\
$\begin{array}{c}\text { Henderson \& } \\
\text { Pabis }\end{array}$ & $\mathrm{MR}=a \exp (-\mathrm{kt})$ & (Akpinar et al., 2003) \\
Wang \& Singh & $\mathrm{MR}=1+a \mathrm{t}+b \mathrm{t}^{2}$ & (Yildiz \& İzli, 2019) \\
Midilli et al. & $\mathrm{MR}=a \exp \left(-\mathrm{kt} \mathrm{t}^{\mathrm{n}}\right)+b \mathrm{t}$ & (Midilli et al., 2002) \\
Diffusion & $\mathrm{MR}=\alpha \exp (-\mathrm{kt})+(1-a) \exp (-\mathrm{k} b \mathrm{t})$ & (Yaldiz et al., 2001) \\
\hline
\end{tabular}

Table 2. Codes for treatments.

\begin{tabular}{ccc}
\hline Treatment & $\begin{array}{c}\text { Ultrasound pretreatment time } \\
(\mathrm{min})\end{array}$ & $\begin{array}{c}\text { Microwave Power } \\
\text { (Watt) }\end{array}$ \\
\hline $180 \mathrm{~W}$ & - & 180 \\
$450 \mathrm{~W}$ & - & 450 \\
$800 \mathrm{~W}$ & - & 800 \\
$5 \mathrm{US}+180 \mathrm{~W}$ & 5 & 180 \\
$5 \mathrm{US}+450 \mathrm{~W}$ & 5 & 450 \\
$5 \mathrm{US}+800 \mathrm{~W}$ & 5 & 800 \\
10US+180W & 10 & 180 \\
10US+450W & 10 & 450 \\
10US+800W & 10 & 800 \\
\hline
\end{tabular}

power levels and ultrasound times was plotted. Drying data of the green olive slices were fitted to four thin drying models (Table 2). SAS 9.4. (SAS Institute Inc., Cary, NC) was used to perform regression analyses. To identify the goodness of fit coefficient of determination $\left(\mathrm{R}^{2}\right), \chi^{2}$ (reduced chi-square parameter) and root mean square error (RMSE) between the predicted and experimental values were applied (Akpinar et al. 2003).

The rehydration kinetics of olive slices dried at different microwave power levels were investigated by Peleg's model which is calculated with the Equation 4:

$\mathrm{X}^{\prime}=1 \pm \frac{\mathrm{t}}{\mathrm{K}_{1+} \mathrm{K}_{2} \mathrm{t}}$

Where $\mathrm{X}_{0}$ is initial moisture content (g water/g dry matter) and $\mathrm{X}$ is the moisture content at time $\mathrm{t}, \mathrm{t}$ is time, $\mathrm{K}_{1}$ is the Peleg rate constant, and $\mathrm{K}_{2}$ is the Peleg capacity constant. When process is an absorption/adsorption \pm turns ' + ' if the process is drying/desorption, \pm turnes to '-'(Planinić et al., 2005). Root mean square error (RMSE), reduced chi-squared value $(\chi 2)$ and coefficient of determination $\left(R^{2}\right)$ were calculated to evaluate the goodness of model fitting.

\subsection{Effective diffusivity}

Effective diffusivity of olive slices was calculated by using the Fick's second diffusion law for slab geometry which is shown in Equation 5:

$$
\frac{\partial \mathrm{M}}{\partial \mathrm{t}}=\mathrm{D}_{\text {eff }} \nabla^{2} \mathrm{M}
$$

Where $\mathrm{D}_{\text {eff }}$ is the effective moisture diffusivity $\left(\mathrm{m}^{2} / \mathrm{s}\right), \mathrm{M}$ is the moisture content (dry basis), $t$ is the time(s) (Yağcioğlu et al., 2014). Fick's second diffusion law presumes that moisture removal is caused by diffusion, temperature, shrinkage and constant diffusion coefficients (Aregbesola et al., 2015; Sun, 2014) 


$$
M R=\frac{M_{t}-M_{e}}{M_{0}-M_{e}}=\frac{8}{\pi^{2}} \sum_{n=0}^{\infty} \frac{1}{(2 n+1)^{2}} \exp \left[-\frac{(2 n+1)^{2} \pi^{2} D_{e f f}}{4 L^{2}}\right]
$$

Where $t$ is time (s), $\mathrm{L}$ is half thickness of samples $(\mathrm{m})$ and $\mathrm{n}$ is a positive integer. For longer drying times, Equation 6 can be converted to a further formula shown in Equation 7 consisting of only the first set of terms without significant influence on the correctness of the supposition.

$$
\begin{aligned}
& \mathrm{MR}=\frac{8}{\pi^{2}} \exp \left[-\frac{\pi^{2} \mathrm{D}_{\text {eff }}}{4 \mathrm{~L}^{2}}\right] \\
& \ln (\mathrm{MR})=\ln \left(\frac{8}{\pi^{2}}\right)-\left[\frac{\pi^{2} \mathrm{D}_{\text {eff }}}{4 \mathrm{~L}^{2}}\right]
\end{aligned}
$$

From Equation 8, moisture effective diffusivity can be determined by plotting $\ln (\mathrm{MR})$ versus drying time $(\mathrm{t})$; which provides a linear line and the slope of this line is explained as Equation 9:

$$
\text { Slope }=\left[\frac{\pi^{2} \mathrm{D}_{\text {eff }}}{4 \mathrm{~L}^{2}}\right]
$$

\subsection{Total Phenolic Content (TPC)}

Total phenolic compounds of green olive slices were determined using Folin-Ciocalteau method (İçier et al., 2015). According to this method, 2 gr of olive slices extracted in a $50 \mathrm{~mL}$ of methanol solution (80:20), then extract was filtered. $50 \mu \mathrm{L}$ of filtered extract was reacted by $250 \mu \mathrm{L}$ Folin-Ciocalteau reagent for 5 minutes. After $750 \mu \mathrm{L}$ of $\mathrm{Na}_{2} \mathrm{CO}_{3}$ was added the volume was completed with $3.95 \mathrm{ml}$ of distilled water. Final solution was kept at $2 \mathrm{~h}$ in dark and the absorbance value was measured using an UV-VİS spectrophotometer at $760 \mathrm{~nm}$.

\subsection{Color parameters}

The color parameters of green olive slices was measured with a Chroma Meter (Konica Minolta, CR 300 Model, VA) based on 5 color coordinates $\left(\mathrm{L}^{*}, \mathrm{a}^{\star}, \mathrm{b}^{\star}, \mathrm{C}, \mathrm{h}^{\circ}\right)$. After the calibration of colorimeter against a standard white surface and green one, six replicate measurements were performed for each sample To illustrate the color changes between control sample and samples after drying treatments total color variance $(\Delta \mathrm{E})$ values were calculated by using the formula shown in Equation 10:

$\Delta \mathrm{E}=\left[(\Delta \mathrm{L} *)^{2}+(\Delta \mathrm{a} *)^{2}+\left(\Delta \mathrm{b}^{* 2}\right)\right]^{1 / 2}$

Where: $\Delta \mathrm{L}^{*}, \Delta \mathrm{a}^{*}$, and $\Delta \mathrm{b}^{*}$ are the differences of these values between the control sample and samples after drying treatment

\subsection{Statistical analysis}

The data was shown as means \pm standard deviation (SD). SAS 9.4. (SAS Institute Inc., Cary, NC, USA) was used to determine the effect of the microwave power level and ultrasound time on the qualitative parameters of olive samples by one-way ANOVA. Tukey's honestly significant differences (HSD) test $(\alpha=0.05)$ was applied as post-hoc test. Coefficient of determination $\left(\mathrm{R}^{2}\right)$, $\chi 2$ (reduced chi-square parameter) and root mean square error (RMSE) were calculated to interpret the adequacy of each model.

\section{Results and discussions}

\subsection{Drying kinetics}

Figure 1 shows the moisture rates of green olives during drying at different microwave power levels and ultrasound pretreatment times. The total drying time for olive slices was 849 second at microwave level of $180 \mathrm{~W}$ and when 10 minutes of sonication applied before drying at $800 \mathrm{~W}$ microwave level it was reduced to 488 seconds. This demonstrates that increasing of microwave level and ultrasound exposure time decreases the total drying time up to $\% 42.5$.

Horuz et al. (2017) also observed that application of ultrasound pre-treatment reduced the drying time of tomato slices by $7.38 \%$ when they were dried at $120 \mathrm{~W}$ microwave power. It was also determined by the researcher that ultrasound pretreatment caused shorter drying times (Bozkir et al., 2018; Rodrigues \& Fernandes, 2007; Seidi Damyeh et al., 2016).

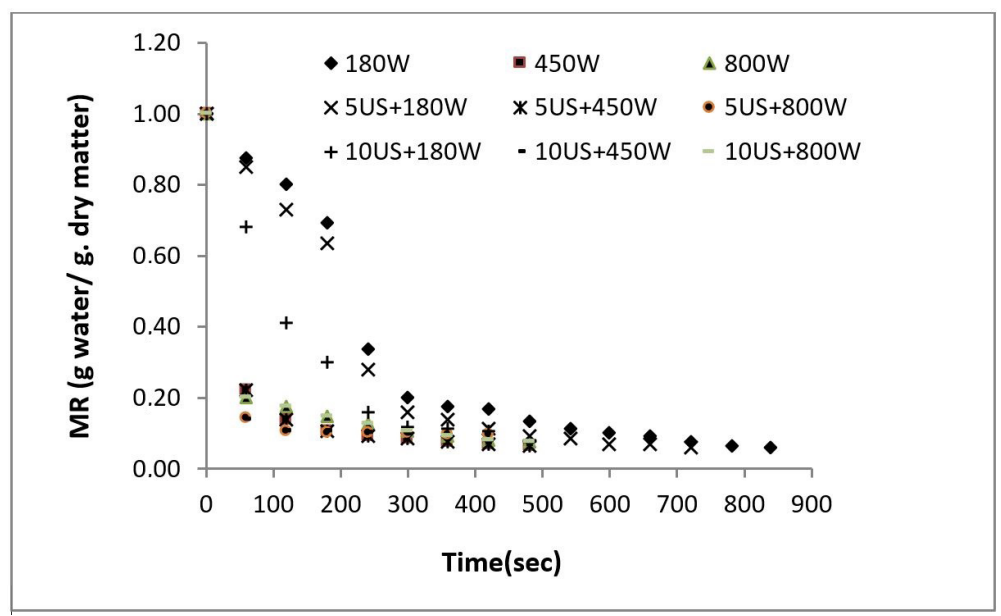

Figure 1. Moisture ratios(MR) of green olives during microwave drying. 
The results of nonlinear analysis of the fitting of four selected models to the rying data of green olive slices at the different ultrasound pretreatment times (5 and $10 \mathrm{~min}$.) and microwave power levels $(180,450$ and $800 \mathrm{~W}$ ) are shown in Table 3. According to the evaluation criteria $\left(\mathrm{R}^{2}, \chi^{2}\right.$ and RMSE), most of models well fitted with the thin layer drying characteristics $\left(\mathrm{R}^{2}>0.9746\right.$, RMSE $<0.0773$ and $\left.\chi 2<0.0065\right)$ of olive slices which are subjected to 5 minute of ultrasound before being dried at $180 \mathrm{~W}$ power level in microwave.

Wang \& Sing and Midilli et al., were the best fitted models in describing the thin layer drying characteristics of olive slices which are not pretreated with ultrasound with the lowest RMSE and $\mathrm{X}^{2}$ values and highest $\mathrm{R}^{2}$ values. 0.9767, 0.9954 and 0.9999 were found the highest $\mathrm{R}^{2}$ values for $180 \mathrm{~W}$, $450 \mathrm{~W}$ and $800 \mathrm{~W}$ microwave dried olive samples, respectively. In a similar study by İzli et al. (2019), Page and Midilli et al. models were best fitted in describing the thin layer microwave drying kinetics of lime slices (Izli et al., 2019). In ultrasound combined microwave drying conditions Wang \& Sing model did not well described the drying characteristics, however Henderson \& Pabis, Distribution and Midilli et al. models well fitted the experimental data with $\mathrm{R}^{2}$ values higher than 0.9954 , RMSE and $\chi 2$ values lower than 0.0792 and 0.0077 , respectively.

\subsection{Effective diffusivities and rehydration kinetics}

Table 4 demonstrates the effective moisture diffusivity $\left(\mathrm{D}_{\text {eff }}\right)$ values for each treatment. Among all samples, Deff value observed highest at $10 \mathrm{~min}$ ultrasound pretreated $800 \mathrm{~W}$ microwave drying $\left(2.21 \times 10^{-8} \mathrm{~m}^{2} / \mathrm{s}\right)$ and lowest at $180 \mathrm{~W}$ microwave drying $\left(9.13 \times 10^{-9} \mathrm{~m}^{2} / \mathrm{s}\right)$.

A higher $\mathrm{D}_{\text {eff }}$ value demonstrated that the moisture removal rate in the green olive slices was greater, which would reduce the drying time to obtain the final moisture content. It was observed that the $\mathrm{D}_{\text {eff }}$ values increased with increase in both with ultrasound pretreatment time and microwave power

Table 3. Coefficients of drying kinetics of green olive slices for different treatments.

\begin{tabular}{|c|c|c|c|c|c|}
\hline Model & Treatment & Model Coefficients & $\mathrm{R}^{2}$ & RMSE & $\mathrm{X}^{2}$ \\
\hline \multirow[t]{9}{*}{ Henderson \& Pabis } & $180 \mathrm{~W}$ & $\mathrm{a}: 1.091 \mathrm{k}: 0.0040$ & 0.9732 & 0.0198 & 0.0059 \\
\hline & $450 W$ & a:0.988 k:0.0046 & 0.9911 & 0.0241 & 0.0052 \\
\hline & $800 W$ & $\mathrm{a}: 0.979 \mathrm{k}: 0.0193$ & 0.9789 & 0.0324 & 0.0094 \\
\hline & $5 \mathrm{US}+180 \mathrm{~W}$ & $\mathrm{a}: 1.083 \mathrm{k}: 0.0046$ & 0.9742 & 0.0778 & 0.0066 \\
\hline & $5 \mathrm{US}+450 \mathrm{~W}$ & a:0.996 k:0.0269 & 0.9953 & 0.0543 & 0.0040 \\
\hline & $5 \mathrm{US}+800 \mathrm{~W}$ & a:0.999 k:1.8402 & 0.9988 & 0.0991 & 0.0112 \\
\hline & $10 \mathrm{US}+180 \mathrm{~W}$ & $\mathrm{a}: 1.001 \mathrm{k}: 0.0069$ & 0.9559 & 0.0128 & 0.0040 \\
\hline & 10US+450W & a:1.000 k:1.8402 & 0.9989 & 0.0409 & 0.0117 \\
\hline & $10 \mathrm{US}+800 \mathrm{~W}$ & $\mathrm{a}: 1.000 \mathrm{k}: 0.4805$ & 0.9992 & 0.0310 & 0.0077 \\
\hline \multirow[t]{9}{*}{ Wang \& Singh } & $180 \mathrm{~W}$ & $\mathrm{a}:-0.0028 \mathrm{k}:-2.1 \times 10^{-6}$ & 0.9767 & 0.0707 & 0.0053 \\
\hline & $450 \mathrm{~W}$ & $\mathrm{a}:-0.0086 \mathrm{k}: 1.8 \times 10^{-5}$ & 0.5954 & 0.1317 & 0.1378 \\
\hline & 800W & $\mathrm{a}:-0.0073 \mathrm{k}: 1.3 \times 10^{-5}$ & 0.7992 & 0.1633 & 0.0501 \\
\hline & $5 \mathrm{US}+180 \mathrm{~W}$ & $\mathrm{a}:-4.3 \times 10^{-9} \mathrm{k}:-2.7 \times 10^{-6}$ & 0.7445 & 0.3690 & 0.1485 \\
\hline & $5 \mathrm{US}+450 \mathrm{~W}$ & $\mathrm{a}:-0.0090 \mathrm{k}: 1.9 \times 10^{-5}$ & 0.8016 & 0.1555 & 0.0591 \\
\hline & $5 \mathrm{US}+800 \mathrm{~W}$ & $\mathrm{a}:-0.0069 \mathrm{k}: 1.2 \times 10^{-5}$ & 0.8313 & 0.1999 & 0.0457 \\
\hline & $10 \mathrm{US}+180 \mathrm{~W}$ & a:-0.0050 k:-0.0001 & 0.9965 & 0.0271 & 0.0008 \\
\hline & 10US+450W & a:- $0.0089 \mathrm{k}:-1.9 \times 10^{-5}$ & 0.6901 & 0.1783 & 0.0371 \\
\hline & $10 \mathrm{US}+800 \mathrm{~W}$ & $\mathrm{a}:-0.0079 \mathrm{k}:-1.5 \times 10^{-5}$ & 0.8334 & 0.1984 & 0.0449 \\
\hline \multirow[t]{9}{*}{ Midilli et al. } & $180 \mathrm{~W}$ & a:1.0905 b:-4.3X10-6 k: 0.5129 n:0.0078 & 0.9733 & 0.0768 & 0.0064 \\
\hline & $450 W$ & a:0.9948 b: $0.0002 \mathrm{k:} 1.2273$ n:0.0188 & 0.9954 & 0.0347 & 0.0014 \\
\hline & 800W & a:0.9917 b: 0.0002 k: 1.2288 n:0.0189 & 0.9999 & 0.0564 & 0.0036 \\
\hline & $5 \mathrm{US}+180 \mathrm{~W}$ & $\mathrm{a}: 1.0772 \mathrm{~b}: 3.2 \mathrm{X} 10^{-5} \mathrm{k}: 0.019 \mathrm{n}: 0.2322$ & 0.9746 & 0.0773 & 0.0065 \\
\hline & $5 \mathrm{US}+450 \mathrm{~W}$ & a:0.9985 b: 0.0002 k: 1.1623 n:0.0252 & 0.9977 & 0.0184 & 0.0005 \\
\hline & $5 \mathrm{US}+800 \mathrm{~W}$ & a:0.9986 b: 0.0003 k: $0.7841 \mathrm{n}: 0.0420$ & 0.9959 & 0.0231 & 0.0008 \\
\hline & $10 \mathrm{US}+180 \mathrm{~W}$ & a:1.0127 b: $0.0001 \mathrm{k}: 1.6932 \mathrm{n}: 0.0044$ & 0.9972 & 0.0170 & 0.0004 \\
\hline & 10US+450W & a:0.9989 b: 0.0003 k: 0.9837 n:0.0339 & 0.9961 & 0.0309 & 0.0011 \\
\hline & $10 \mathrm{US}+800 \mathrm{~W}$ & a:0.9992 b: 0.0002 k: 1.0290 n:0.0356 & 0.9879 & 0.0226 & 0.0008 \\
\hline \multirow[t]{9}{*}{ Diffusion } & $180 \mathrm{~W}$ & a:-6.4668 b:1.0593:k:0.0024 & 0.9725 & 0.0811 & 0.0071 \\
\hline & $450 W$ & a: -19.0371 b:1.0001:k:0.0207 & 0.9916 & 0.0725 & 0.0060 \\
\hline & $800 \mathrm{~W}$ & a: -12.5001 b:1.0000:k:0.0197 & 0.9802 & 0.0976 & 0.0108 \\
\hline & $5 \mathrm{US}+180 \mathrm{~W}$ & a: 0.1471 b:20.4320:k:0.0018 & 0.9748 & 0.0047 & $2.59 \times 10^{-4}$ \\
\hline & $5 \mathrm{US}+450 \mathrm{~W}$ & a: 0.1104 b:118.9220:k:0.0004 & 0.9998 & 0.0026 & $8.00 \times 10^{-5}$ \\
\hline & $5 \mathrm{US}+800 \mathrm{~W}$ & a:-5.8901 b:1.0824 k:0.0024 & 0.9999 & 0.0792 & 0.0068 \\
\hline & 10US+180W & a:-1.0748 b:0.9999 k:0.0068 & 0.9962 & 0.0292 & 0.0010 \\
\hline & $10 \mathrm{US}+450 \mathrm{~W}$ & a:0.1180 b:80.7682 k:0.0007 & 0.9999 & 0.0013 & $2.11 \times 10^{-6}$ \\
\hline & $10 \mathrm{US}+800 \mathrm{~W}$ & $\mathrm{a}: 0.1011 \mathrm{~b}: 86.0857 \mathrm{k}: 0.0007$ & 0.9802 & 0.0013 & $1.48 \times 10^{-6}$ \\
\hline
\end{tabular}


level. Since, high microwave power levels cause an increase in the water molecule activity at elevated drying temperatures, moisture diffusion increases in samples.

Highest drying rates were observed in microwave drying at $800 \mathrm{~W}$ power level when combined with sonication 10 and 5 minutes, respectively. The drying rate of ultrasound non-treated samples was lower in comparison to pretreated samples and effective diffusion coefficients were increased as ultrasound time increased at same power level.

Figure 2 demonstrates rehydration curves of olive slices dried at different microwave powers combined by ultrasound. As it can be seen in this figure, the when microwave power increased in drying procedure the rehydration ratio decreased during time. The smaller values for $\mathrm{k} 2$ values of rehydration demonstrates better water absorption properties was confirmed for olives dried at lower microwave power levels. It was also resulted that increasing microwave power up to $800 \mathrm{~W}$ and ultrasound induced lower rehydration capacity of dried samples. Although ultrasound pretreatment forms micro channels which promotes a faster dehydration, microwave drying cause irreversible cell rupture in fruit tissue that reduces the water absorption at higher microwave power levels. Rehydration kinetics of olive slices calculated by Peleg's model were fitted in all drying treatments
$\left(\mathrm{R}^{2}>0.9979, \mathrm{RMSE}<0.0252\right.$ and $\left.\chi 2<0.0063\right)$ are demonstrated in Table 4. It was found that both $\mathrm{k} 1$ and $\mathrm{k} 2$ values increased as ultrasound time and microwave power have risen. Horuz et al. (2017) observed that $\mathrm{k} 1$ value of dried tomato slices increases and $\mathrm{k} 2$ value of dried tomato slices decreases as ultrasound time increases. Differences in rehydration behavior in this study may result from being studied at higher microwave power levels and lower ultrasound times.

\subsection{Color parameters and total phenolic content}

$\mathrm{L}^{*}$ (lightness) values of olive slices dried at $180 \mathrm{~W}$, $450 \mathrm{~W}$ and $800 \mathrm{~W}$ power level were not significantly different from control sample however they were lower than control sample in all 3 treatment which can be explained by non-enzymatic oxidation reaction. However, the decrease in $L^{*}$ value was not observed in most samples which ultrasound applied. In most of these drying conditions which are pretreated by ultrasound, $\mathrm{L}^{*}$ value was higher than control except the 5 and 10 minute ultrasound pretreated microwave dried olive samples at $180 \mathrm{~W}$ power . Bozkur et al., also studied the ultrasound pretreatment effect on quality and drying parameters found that lightness was lowest at microwave dried samples and highest at hot air dried samples (Bozkir et al., 2018).

Table 4. Effective diffusivities of different drying experiments and coefficients of rehydration kinetics calculated by Peleg's Model.

\begin{tabular}{|c|c|c|c|c|c|c|}
\hline \multirow{2}{*}{ Treatment } & \multirow{2}{*}{ Moisture Effective Diffusivity $\left(\mathrm{m}^{2} / \mathrm{s}\right)$} & \multicolumn{5}{|c|}{ Coefficients of rehydration kinetics } \\
\hline & & $\mathrm{K}_{1}$ & $\mathrm{~K}_{2}$ & $\mathrm{R}^{2}$ & RMSE & $x^{2}$ \\
\hline $180 \mathrm{~W}$ & $9.13 \times 10^{-09}$ & 0.2382 & 0.1557 & 0.9991 & 0.0196 & 0.0038 \\
\hline $450 W$ & $1.12 \times 10^{-08}$ & 0.2849 & 0.1778 & 0.9980 & 0.0252 & 0.0063 \\
\hline $800 \mathrm{~W}$ & $1.17 \times 10^{-08}$ & 0.3373 & 0.1894 & 0.9986 & 0.0190 & 0.0036 \\
\hline $5 U S+180 \mathrm{~W}$ & $1.09 \times 10^{-08}$ & 0.2475 & 0.1513 & 0.9989 & 0.0167 & 0.0028 \\
\hline $5 \mathrm{US}+450 \mathrm{~W}$ & $1.22 \times 10^{-08}$ & 0.3009 & 0.1749 & 0.9979 & 0.0236 & 0.0056 \\
\hline $5 \mathrm{US}+800 \mathrm{~W}$ & $2.10 \times 10^{-08}$ & 0.3538 & 0.1837 & 0.9986 & 0.0123 & 0.0015 \\
\hline $10 \mathrm{US}+180 \mathrm{~W}$ & $1.45 \times 10^{-08}$ & 0.2706 & 0.1659 & 0.9984 & 0.0246 & 0.0060 \\
\hline $10 \mathrm{US}+450 \mathrm{~W}$ & $2.05 \times 10^{-08}$ & 0.3483 & 0.1820 & 0.9988 & 0.0183 & 0.0033 \\
\hline $10 \mathrm{US}+800 \mathrm{~W}$ & $2.21 \times 10^{-08}$ & 0.3579 & 0.2239 & 0.9997 & 0.0069 & 0.0004 \\
\hline
\end{tabular}

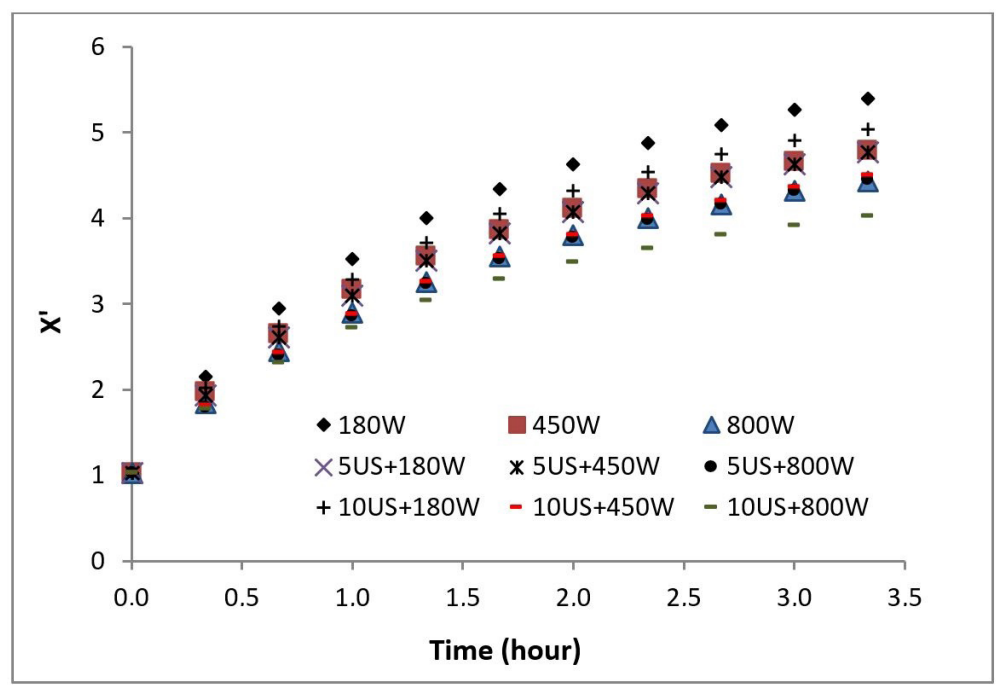

Figure 2. Rehydration ratio-time profiles for ultrasound pretreated microwave dried olive slices. 
Table 5. Color parameters and total phenolic contents of olives.

\begin{tabular}{|c|c|c|c|c|c|c|c|}
\hline Treatments & $L^{*}$ & $a^{*}$ & $b^{*}$ & $\Delta \mathrm{E}$ & $\mathrm{C}$ & $\mathrm{H}^{\circ}$ & $\begin{array}{c}\text { Total Phenolic Content } \\
\text { (mg GA/ } 100 \text { g dry matter) }\end{array}$ \\
\hline Control & $47.93 \pm 0.18^{\mathrm{bcd}}$ & $0.99 \pm 0.03^{\mathrm{abc}}$ & $10.56 \pm 0.17^{a}$ & - & $10.63 \pm 0.19^{a}$ & $84.70 \pm 0.28^{\mathrm{cd}}$ & $92.06 \pm 1.17^{\mathrm{a}}$ \\
\hline $180 \mathrm{~W}$ & $43.13 \pm 1.04^{\mathrm{d}}$ & $0.82 \pm 0.28^{\mathrm{abc}}$ & $10.35 \pm 2.31^{\mathrm{a}}$ & $1.32 \pm 0.06^{\mathrm{e}}$ & $11.66 \pm 0.93^{\mathrm{a}}$ & $85.73 \pm 1.07^{\mathrm{bc}}$ & $73.25 \pm 5.96^{\mathrm{bc}}$ \\
\hline $450 \mathrm{~W}$ & $46.67 \pm 1.40^{\mathrm{bcd}}$ & $0.88 \pm 0.59^{\mathrm{abc}}$ & $10.78 \pm 3.29^{a}$ & $4.87 \pm 0.47^{\text {cde }}$ & $13.53 \pm 0.96^{a}$ & $85.10 \pm 0.53^{\mathrm{bcd}}$ & $64.01 \pm 1.10^{\text {cde }}$ \\
\hline $800 \mathrm{~W}$ & $45.36 \pm 0.95^{\mathrm{dc}}$ & $0.48 \pm 0.03^{\mathrm{bc}}$ & $13.45 \pm 0.69^{\mathrm{a}}$ & $9.22 \pm 0.16^{\mathrm{b}}$ & $13.45 \pm 0.66^{\mathrm{a}}$ & $88.00 \pm 0.20^{\mathrm{a}}$ & $46.56 \pm 2.84^{\mathrm{fg}}$ \\
\hline 5US+180W & $47.61 \pm 0.32^{\mathrm{bcd}}$ & $0.89 \pm 0.06^{\mathrm{abc}}$ & $12.21 \pm 0.41^{\mathrm{a}}$ & $1.26 \pm 0.17^{\mathrm{e}}$ & $12.23 \pm 0.41^{\mathrm{a}}$ & $85.95 \pm 0.15^{\mathrm{b}}$ & $76.91 \pm 2.52^{\mathrm{b}}$ \\
\hline $5 \mathrm{US}+450 \mathrm{~W}$ & $54.45 \pm 5.29^{\mathrm{a}}$ & $0.37 \pm 0.06^{c}$ & $13.93 \pm 2.52^{\mathrm{a}}$ & $16.83 \pm 1.93^{\mathrm{a}}$ & $13.93 \pm 2.52^{\mathrm{a}}$ & $88.53 \pm 0.06^{\mathrm{a}}$ & $66.54 \pm 3.42^{\text {cde }}$ \\
\hline $5 \mathrm{US}+800 \mathrm{~W}$ & $51.45 \pm 1.83^{\mathrm{abs}}$ & $1.35 \pm 0.08^{\mathrm{a}}$ & $12.51 \pm 1.95^{\mathrm{a}}$ & $6.02 \pm 1.61^{\mathrm{bcd}}$ & $14.00 \pm 1.16^{\mathrm{a}}$ & $84.10 \pm 0.20^{\mathrm{d}}$ & $56.14 \pm 2.81^{\mathrm{efg}}$ \\
\hline $10 \mathrm{US}+180 \mathrm{~W}$ & $47.20 \pm 1.42^{\mathrm{bcd}}$ & $0.94 \pm 0.21^{\mathrm{abc}}$ & $9.84 \pm 2.68^{\mathrm{a}}$ & $3.04 \pm 0.21^{\mathrm{de}}$ & $10.91 \pm 1.34^{\mathrm{a}}$ & $84.70 \pm 0.10^{\mathrm{cd}}$ & $69.24 \pm 2.67^{\mathrm{bcd}}$ \\
\hline $10 \mathrm{US}+450 \mathrm{~W}$ & $52.14 \pm 2.50^{\mathrm{ab}}$ & $1.33 \pm 0.27^{\mathrm{a}}$ & $14.10 \pm 1.54^{\mathrm{a}}$ & $18.23 \pm 1.72^{\mathrm{a}}$ & $14.16 \pm 1.54^{\mathrm{a}}$ & $84.30 \pm 0.20^{\mathrm{d}}$ & $60.02 \pm 2.02^{\mathrm{def}}$ \\
\hline $10 \mathrm{US}+800 \mathrm{~W}$ & $49.32 \pm 2.38^{\mathrm{abcd}}$ & $1.14 \pm 0.23^{\mathrm{ab}}$ & $12.71 \pm 2.01^{\mathrm{a}}$ & $7.44 \pm 0.46^{\mathrm{bc}}$ & $12.75 \pm 2.03^{\mathrm{a}}$ & $84.83 \pm 0.32^{\mathrm{bcd}}$ & $49.63 \pm 2.27^{\mathrm{fg}}$ \\
\hline
\end{tabular}

Lowest $\mathrm{a}^{*}$ (redness-greenness) value observed in 5 minute ultrasound pretreated microwave dried olive samples at $450 \mathrm{~W}$ power among all treatments. $\mathrm{a}^{\star}$ values of microwave dried samples were not significantly different $(p>0.05)$. It was also found that ultrasound pretreatment did not make significant differences in $b^{*}$ (yellowness-blueness) and $c^{*}$ values of all samples $(\mathrm{p}>0.05)$. While total color difference $(\Delta \mathrm{E})$ values of ultrasound treated olive slices were between 1.26-18.23, it was 1.32-9.22 for non treated samples. Horuz et al. (2017) reported that $\Delta \mathrm{E}$ values of all microwave drying conditions combined by ultrasound was not higher than 10 in tomato samples. It was found that the color of olive slices differed significantly in ultrasound pretreated olives dried at $450 \mathrm{~W}$ compared to control sample. The changes in $\mathrm{L}^{\star}$ value of olive slices were more clearly observed than in Hue angle (Table 5).

Total phenolic contents of green table olive slices reduced significantly in all microwave and ultrasound pretreated drying treatments compared to control sample $(p<0.05)$. The decrease in phenolic compounds might be related to deterioration of these compounds by electromagnetic waves of the microwave. In addition, microwave power induced to the internal temperature of food to rise due to the friction of the water molecules. Thus, thermal degradation and irreversible oxidative reactions caused phenolic compounds to be damaged during drying. Total phenolic compounds of olive slices obtained by ultrasound pretreatment were slightly higher when compared to those samples were not ultrasound pretreated. The degradation could be due to sonochemical and oxidation reactions, increased interaction with free radicals during sonication. It can be seen from Table 4 ultrasound pretreated samples preserved phenolics better compared to non-treated samples at each microwave power levels. Highest loss in phenolic compounds were observed when samples were dried at $800 \mathrm{~W}$ microwave power level. When olive slices were dried at $800 \mathrm{~W}$ microwave power, total phenolic compounds were decreased from $92.06 \pm 1.17 \mathrm{mg} \mathrm{GA} / 100 \mathrm{~g}$ olive to $46.56 \pm 2.84 \mathrm{mg} \mathrm{GA} / 100 \mathrm{~g}$ olive. However when samples subjected to 5 and 10 minutes of sonication before microwave drying at $800 \mathrm{~W}$, the phenolic contents were $56.14 \pm 2.81 \mathrm{mg} \mathrm{GA} / 100 \mathrm{~g}$ olive and $49.63 \pm 2.27 \mathrm{mg} \mathrm{GA} / 100 \mathrm{~g}$ olive, respectively. Deterioration of phenolic compounds was also lower in ultrasound pretreated olives dried at $450 \mathrm{~W}$ and $180 \mathrm{~W}$ microwave levels when compared to non pretreated olives dried at same power levels.

\section{Conclusions}

This study concluded that ultrasound application as a pretreatment for microwave drying of green olive slices is a feasible method which reduced the drying time and enhanced the quality of product. Effective diffusion coefficients of $10 \mathrm{~min}$ ultrasound pretreatments were higher than those 5 min ultrasound pretreated and non-ultrasound treated samples. Rehydration ratios were higher for with and without ultrasound-pretreated olive slices dried at 180W microwave power. Midilli et al. and Wang \& Singh models well explained the drying characteristics of MW dried samples $\left(\mathrm{R}^{2}>0.9767\right)$, on the other hand Diffusion, Henderson \& Pabis and Midilli et al. models described US-MW combined drying process more successfully $\left(\mathrm{R}^{2}>0.9746\right)$. Rehydration ratios were higher for with and without ultrasound-pretreated olive slices dried at $180 \mathrm{~W}$ microwave power than samples dried at 450 and $800 \mathrm{~W}$ microwave power. US-MW drying obtained acceptable olive quality with high lightness, and phenolic compounds. It was determined that ultrasound was a promising pretreatment in microwave drying method for green olive slices.

\section{References}

Ahmad, T., Butt, M. Z., Muhammad, R., Inam-ur-raheem, M., Balthazar, C. F., Rocha, R. S., \& Cruz, A. G. (2019). Impact of nonthermal processing on different milk enzymes. Drying Technology, 72, 481-495.

Akpinar, E. K., Bicer, Y., \& Yildiz, C. (2003). Thin layer drying of red pepper. Journal of Food Engineering, 59(1), 99-104. http://dx.doi. org/10.1016/S0260-8774(02)00425-9.

Antal, T., Tarek, M., Tarek-Tilistyák, J., \& Kerekes, B. (2017). Comparative effects of three different drying methods on drying kinetics and quality of Jerusalem Artichoke (Helianthus tuberosus L.). Journal of Food Processing and Preservation, 41(3), e12971. http://dx.doi. org/10.1111/jfpp.12971.

Aregbesola, O. A., Ogunsina, B., Sofolahan, A. E., \& Chime, N. N. (2015). Mathematical modeling of thin layer drying characteristics of dika (Irvingia gabonensis) nuts and kernels. Nigerian Food Journal, 33(1), 83-89. http://dx.doi.org/10.1016/j.nifoj.2015.04.012.

Aydar, A., Öncü Öner, T., \& Ücok, E. F. (2017a). Effects of Hydroxytyrosol on Human Health, 11, 147-157.

Aydar, A. Y., Bağdatlığlu, N., \& Köseoğlu, O. (2017b). Effect of ultrasound on olive oil extraction and optimization of ultrasoundassisted extraction of extra virgin olive oil by response surface methodology (RSM). Grasas y Aceites. 68(2), 189. 
Bozkir, H., Rayman Ergün, A., Tekgül, Y., \& Baysal, T. (2018). Ultrasound as pretreatment for drying garlic slices in microwave and convective dryer. Food Science and Biotechnology, 28(2), 347-354. http://dx.doi. org/10.1007/s10068-018-0483-1. PMid:30956846.

Fijalkowska, A., Nowacka, M., Wiktor, A., Witrowa-Rajchert, D., \& Sledz, M. (2016). Ultrasound as a pretreatment method to improve drying kinetics and sensory properties of dried apple. Journal of Food Process Engineering, 39(3), 256-265.

Guimarães, J. T., Silva, E. K., Alvarenga, V. O., Costa, A. L. R., Cunha, R. L., Sant'Ana, A. S., Freitas, M. Q., Meireles, M. A. A., \& Cruz, A. G. (2018). Physicochemical changes and microbial inactivation after high-intensity ultrasound processing of prebiotic whey beverage applying different ultrasonic power levels. Ultrasonics Sonochemistry, 44, 251-260. http://dx.doi.org/10.1016/j.ultsonch.2018.02.012. PMid:29680610.

Guimarães, J. T., Balthazar, C. F., Scudino, H., Pimentel, T. C., Esmerino, E. A., Ashokkumar, M., Freitas, M. Q., \& Cruz, A. G.. (2019a). Highintensity ultrasound: a novel technology for the development of probiotic and prebiotic dairy products. Ultrasonics Sonochemistry, 57, 12-21. http://dx.doi.org/10.1016/j.ultsonch.2019.05.004. PMid:31208607.

Guimarães, J. T., Silva, E. K., Ranadheera, C. S., Moraes, J., Raices, R. S. L., Silva, M. C., Ferreira, M. S., Freitas, M. Q., Meireles, M. A. A., \& Cruz, A. G. (2019b). Effect of high-intensity ultrasound on the nutritional profile and volatile compounds of a prebiotic soursop whey beverage. Ultrasonics Sonochemistry, 55, 157-164. http://dx.doi. org/10.1016/j.ultsonch.2019.02.025. PMid:30853535.

Horuz, E., Jaafar, H. J., \& Maskan, M. (2017). Ultrasonication as pretreatment for drying of tomato slices in a hot air - microwave hybrid oven. Drying Technology, 35(7), 849-859. http://dx.doi.org/ 10.1080/07373937.2016.1222538.

Huang, D., Men, K., Li, D., Wen, T., Gong, Z., Sunden, B., \& Wu, Z. (2019). Application of ultrasound technology in the drying of food products. Ultrasonics Sonochemistry, 63, 104950. http://dx.doi. org/10.1016/j.ultsonch.2019.104950. PMid:31952007.

İçier, F., Baysal, T., Taştan, Ö., \& Özkan, G. (2015). Microwave drying of black olive slices : effects on total phenolic contents and colour. Gida/The Journal of Food, 39(6), 323-330. http://dx.doi.org/10.15237/ gida.GD14030.

Izli, N., Taskin, O., \& Izli, G. (2019). Drying of lime slices by microwave and microwave combined convective methods. Italian Journal of Food Science, 31(3), 487-500.

Jiménez, A., Beltrán, G., \& Uceda, M. (2007). High-power ultrasound in olive paste pretreatment. Effect on process yield and virgin olive oil characteristics. Ultrasonics Sonochemistry, 14(6), 725-731. http:// dx.doi.org/10.1016/j.ultsonch.2006.12.006. PMid:17275391.

Kailis, S. G. (2016). Olives. Encyclopedia of Applied Plant Sciences, 3, 236-245.

Midilli, A., Kucuk, H., \& Yapar, Z. (2002). A new model for singlelayer drying. Drying Technology, 20(7), 1503-1513. http://dx.doi. org/10.1081/DRT-120005864.

Planinić, M., Velić, D., Tomas, S., Bilić, M., \& Bucić, A. (2005). Modelling of drying and rehydration of carrots using Peleg s model. European
Food Research and Technology, 221(3-4), 446-451. http://dx.doi. org/10.1007/s00217-005-1200-x.

Rawson, A., Tiwari, B. K., Tuohy, M. G., O’Donnell, C. P., \& Brunton, N. (2011). Effect of ultrasound and blanching pretreatments on polyacetylene and carotenoid content of hot air and freeze dried carrot discs. Ultrasonics Sonochemistry, 18(5), 1172-1179. http:// dx.doi.org/10.1016/j.ultsonch.2011.03.009. PMid:21486706.

Rodrigues, S., \& Fernandes, F. A. N. (2007). Use of ultrasound as pretreatment for dehydration of melons. Drying Technology, 25(10), 1791-1796. http://dx.doi.org/10.1080/07373930701595409.

Rodríguez, R., Lombraña, J. I., \& Lombran, J. I. (2007). Moisture diffusivity analysis in a microwave drying process under different operating conditions moisture diffusivity analysis in a microwave drying process under different operating conditions. Journal Drying Technology an International Journal, 25(11), 1875-1883.

Seidi Damyeh, M., Niakousari, M., \& Saharkhiz, M. J. (2016). Ultrasound pretreatment impact on Prangos ferulacea Lindl. and Satureja macrosiphonia Bornm. essential oil extraction and comparing their physicochemical and biological properties. Industrial Crops and Products, 87, 105-115. http://dx.doi.org/10.1016/j.indcrop.2016.04.025.

Simal, S., Femenia, A., Garau, M. C., \& Rosselló, C. (2005). Use of exponential, Page's and diffusional models to simulate the drying kinetics of kiwi fruit. Journal of Food Engineering, 66(3), 323-328. http://dx.doi.org/10.1016/j.jfoodeng.2004.03.025.

Sun, D.-W. (2014). Emerging technologies for food processing (2nd ed.). Dublin: Elsevier Inc.

Sunil, C. K., Kamalapreetha, B., Sharathchandra, J., Aravind, K. S., \& Rawson, A. (2017). Effect of ultrasound pre-treatment on microwave drying of okra. Journal of Applied Horticulture, 19(1), 58-62. http:// dx.doi.org/10.37855/jah.2017.v19i01.09.

Tang, X., Cronin, D. A., \& Brunton, N. P. (2005). The effect of radio frequency heating on chemical, physical and sensory aspects of quality in turkey breast rolls. Food Chemistry, 93(1), 1-7. http:// dx.doi.org/10.1016/j.foodchem.2004.08.037.

Wang, J., Xiao, H. W., Ye, J. H., Wang, J., \& Raghavan, V. (2019). Ultrasound Pretreatment to Enhance Drying Kinetics of Kiwifruit (Actinidia deliciosa) Slices: Pros and Cons. Food and Bioprocess Technology, 12(5), 865-876. http://dx.doi.org/10.1007/s11947-019-02256-4.

Yağcioğlu, A., Demir, V., \& Günhan, T. (2014). Effective moisture diffusivity estimation from drying data. Tarm Makinaları Bilimi Dergisi, 3(4), 249-256.

Yaldiz, O., Ertekin, C., \& Uzun, H. I. (2001). Mathematical modeling of thin layer solar drying of sultana grapes. Energy, 26(5), 457-465. http://dx.doi.org/10.1016/S0360-5442(01)00018-4.

Yildiz, G., \& İzli, G. (2019). Influence of microwave and microwaveconvective drying on the drying kinetics and quality characteristics of pomelo. Journal of Food Processing and Preservation, 43(6), 1-11. http://dx.doi.org/10.1111/jfpp.13812.

Zhang, Z., Liu, Z., Liu, C., Li, D., Jiang, N., \& Liu, C. (2016). Effects of ultrasound pretreatment on drying kinetics and quality parameters of button mushroom slices. Drying Technology, 15(34), 1791-1800. http://dx.doi.org/10.1080/07373937.2015.1117486. 